\section{Multi-metallic contamination around former uranium mines induces adverse effects and acclimation disturbance in three-spined stickleback (Gasterosteus aculeatus)}

\section{A. Le Guernic,, ${ }^{1,2}$ W. Sanchez, ${ }^{1}$ \\ S. Betoulle, ${ }^{3}$ B. Gagnaire ${ }^{2}$}

'Institut National de l'Environnement industriel et des RISques (INERIS), UMR-I 02 SEBIO, Verneuil en Halatte; Institut de Radioprotection et de Sûreté Nucléaire (IRSN), pôle environnement, laboratoire d'écotoxicologie des radionucléides, Saint-Paul lez Durance;

3Université de Reims ChampagneArdenne (URCA), UMR-I 02 SEBIO, Reims, France

\section{Introduction}

Uranium extraction is a worldwide activity during which thousands of tons of ores can be recovered, but also million tons of tailings and waste rocks are stored on mine sites, also containing uranium and its decay products. These activities result in a uranium contamination of surrounding aquatic ecosystems. In addition to this uranium contamination, the aquatic environment can present significant concentrations of heavy metals, naturally occurring due to geographic location (iron and manganese) or coming from anthropogenic activities (aluminium and barium used to precipitate uranium and its decay products). This multi-metallic contamination impacts all compartments of the ecosystem, including the aquatic environment, last refuge of heavy metals. ${ }^{1}$ This is the case in the Haute-Vienne department (Limousin, France), where almost a quarter uranium mines of France were in activity in the twentieth century. In this department, we worked on one former mine area. Several ponds were identified: Pontabrier, a pond which receives wastes and residues from two former uranium mines and two references ponds without uranium [Malessard and Jonchère Saint-Maurice (JSM)]. Heavy metals are known to be toxic for aquatic organisms, including fish. Immune system, antioxidant system and also DNA can be impaired by these pollutants. ${ }^{2-4}$ The presence of this multi-metallic contamination shows the importance to evaluate the environmental risk linked to former uranium mines in France.

For this purpose, three-spined sticklebacks were chosen for in situ caging experiments. This fish species was selected because of its small size, important criterion for caging, and because it is usually adopted in ecotoxicological studies., The aims of this study was: i) to assess several biological responses of three-spined sticklebacks to this multi-metallic contamination; and ii) to observe their acclimation capacities after lipopolysaccharide injections (biological stress).

\section{Materials and Methods}

After two weeks of acclimatization in laboratory to environmental conditions, 90 sticklebacks were caged in the Pontabrier, Malessard and Jonchère Saint-Maurice ponds (15 fish per cage; 2 cages per pond). Fourteen days after caging, fish were anesthetized with MS222 $(0.1 \mathrm{~g} / \mathrm{L})$ and intraperitoneal injections of lipopolysaccharides (LPS; $9 \mathrm{mg}$ LPS/kg fish total weight) or its solvent (phosphate buffer saline) were performed in order to induce a biological stress. Immediately after injections, sticklebacks were returned into cages for four days. Then, sticklebacks were sacrificed in order to recover organs. Spleen and total blood were recovered for analyze immune responses and DNA damage respectively. Total and dissolved water fractions from each pond were collected for assessment of levels of metals, organic and inorganic carbon, major cations and anions, pesticides, polycyclic aromatic hydrocarbons (PAHs), polychlorinated biphenyls (PCBs), volatile organic compounds (VOCs) and cyanobacteria. Finally, $\mathrm{pH}$ and conductivity were recorded at $\mathrm{T} 0, \mathrm{~T} 14$ and $\mathrm{T} 18$ while temperature was continuously recorded (hourly) with a probe.

Fish weight and size were recorded in order to evaluated the general well-being of fish by the Fulton's $K$ condition index ( $K=100 \mathrm{x}$ total weight $(\mathrm{g}) /$ size $\left.(\mathrm{cm})^{3}\right) .{ }^{5}$ Immunomarkers were analyzed by flow cytometry after grinding the spleen through sterilized nylon mesh $(40 \mu \mathrm{m})$. Necrosis, apoptosis, leucocytes distribution, lysosomal membrane integrity (LMI), ROS (Reactive Oxygen Species) production and phagocytic capacity were recorded using a Guava easyCyte ${ }^{\mathrm{TM}}$ cytometer. ${ }^{6}$ Finally, DNA damage were assessed using alkaline comet assay on blood erythrocytes, according to protocol used by Santos et al.

\section{Results and Discussion}

\section{Multi-metallic contamination}

Concerning metal concentrations in water, all major metals (U, Al, Mn, Fe, Ba) were more concentrated in Pontabrier pond compared to Malessard and Jonchère Saint-Maurice ponds, especially for uranium (Table 1). Iron, aluminium and manganese concentrations were over the predicted no effect concentrations (PNEC) ${ }^{8-12}$ for each pond (Table 1). Others metals were present in lower quantities (under their respective PNEC: $\mathrm{Cr}, \mathrm{Pb}, \mathrm{Cd}, \mathrm{Zn}, \mathrm{Cu}, \mathrm{Ni}, \mathrm{Co}$ ). PAH, PCB, VOC, pesticides and cyanobacteria in water were under the detection limits (data not shown).
Correspondence: Antoine Le Guernic, Institut de Radioprotection et de Sûreté Nucléaire (IRSN), pôle environnement, laboratoire d'écotoxicologie des radionucléides, Cadarache, 13115 Saint-Paul lez Durance, France.

Tel.: 33.4.42199632.

E-mail: antoine.leguernic@irsn.fr

Key words: uranium mines, Gasterosteus aculeatus, contamination.

Conference presentation: ECOBIM meeting, 2014 May, Brest, France.

This work is licensed under a Creative Commons Attribution NonCommercial 3.0 License (CC BYNC 3.0).

(C) Copyright A. Le Guernic et al., 2014

Licensee PAGEPress, Italy

Journal of Xenobiotics 2014; 4:4904

doi:10.4081/xeno.2014.4904

\section{Effects of chemical stress}

\section{on stickleback}

Fulton's $\mathrm{K}$ condition index, in laboratory conditions, is around $1 . \mathrm{K}$ of sticklebacks caged in the Pontabrier pond was at $0.83 \pm 0.08$, whereas it was significantly higher $(0.97 \pm 0.12$ and $0.91 \pm 0.07)$ for the two other ponds (data not shown). Concerning immune biomarkers, leucocyte necrosis was lower and basal ROS production was higher in fish caged in Pontabrier pond compared to other ponds (data not shown). Integrity of lysosomal membrane was lower in the Jonchère Saint-Maurice pond than in the Pontabrier pond and even more than in the Malessard pond (data not shown). No significant difference was observed for phagocytosis capacity and apoptosis between ponds for PBS injections. Finally, sticklebacks caged in the Pontabrier pond presented the lowest level of DNA damages (data not shown).

DNA damage compared to fish in the other two ponds (data not shown), but affected some markers of immune system. Indeed, leucocytes necrosis and apoptosis were enhanced when LPS were injected in fish (data not shown). In the same way, LMI decreased after LPS injection compared to PBS injection (data not shown). These results show that LPS alter defense system of sticklebacks. Nevertheless, phagocytosis increased after LPS injection, which could demonstrate an enhancement of defense system towards this stress (Figure 1). Analysis of DNA damages showed an increase of DNA alterations with LPS (data not shown).

When fish were located in the water with the lowest metal concentrations (Jonchère SaintMaurice pond), the effects of LPS were more pronounced. Indeed, the immune-stimulation induced by LPS induced greater increases in DNA damage, leukocyte apoptosis and phagocytosis than in the two other ponds (Figure 1). This sug- 
Table 1. Concentrations ( $\mu \mathrm{g} / \mathrm{L}$ ) and predicted no effect concentrations (PNEC) of major metals found in the Haute-Vienne ponds on dissolved water fraction. Bold concentration values are higher than values of their respective PNEC.

\begin{tabular}{|c|c|c|c|c|c|}
\hline PONDS & $\begin{array}{c}\mathrm{U} \\
\mu \mathrm{g} / \mathrm{L}\end{array}$ & $\begin{array}{c}\mathrm{Al} \\
\mu \mathrm{g} / \mathrm{L}\end{array}$ & $\begin{array}{l}\mathrm{Fe} \\
\mu \mathrm{g} / \mathrm{L}\end{array}$ & $\begin{array}{l}\mathrm{Mn} \\
\mu \mathrm{g} / \mathrm{L}\end{array}$ & $\begin{array}{c}\mathrm{Ba} \\
\mu \mathrm{g} / \mathrm{L}\end{array}$ \\
\hline Po & 29.08 & 79.3 & 319.8 & 37.6 & 53.3 \\
\hline Ma & 0.18 & 59.3 & 205.8 & 23.9 & 41.1 \\
\hline Js & 0.03 & 24.3 & 274.3 & 21.6 & 31.3 \\
\hline PNEC & 0.3 & 0.06 & 16 & 15 & 60 \\
\hline
\end{tabular}

U, uranium; Al, aluminium; Fe, iron; Mn, manganese; Ba, barium; Po, Pontabrier; Ma, Malessard; Js, Jonchère Saint-Maurice ponds.

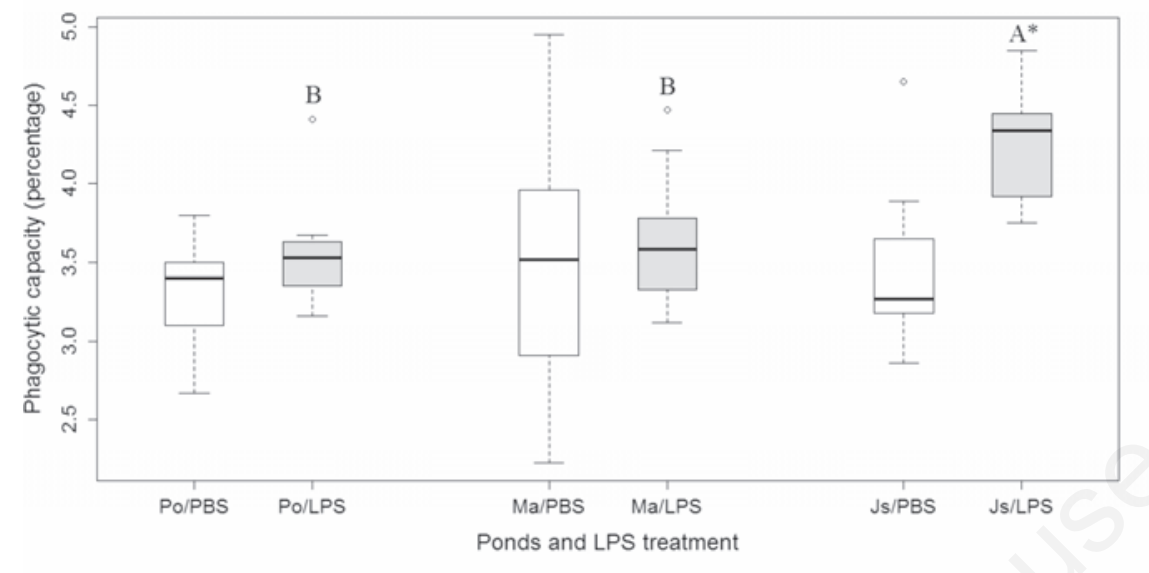

Figure 1. Phagocytic capacity of sticklebacks caged in the Haute-Vienne ponds with (grey) and without (white) injection of LPS. Po, Pontabrier, Ma, Malessard; Js, Jonchère Saint-Maurice ponds. A, B: significant differences between ponds for the same biological stress (LPS), A>B. * Significant difference between PBS and LPS conditions in a same pond.

gests that the higher multi-metallic contaminations in the Pontabrier and Malessard have attenuated LPS-induced effects.

In our study, fish exposed to more polluted sites did not respond to LPS-stimulation, which could indicate that these fish could be susceptible to infections. Other studies revealed the same susceptibility of fish after metal exposure. ${ }^{13,14}$ As many authors have identified confounding factors, represented by environmental factors $(\mathrm{pH}$, conductivity and temperature) and/or physiological parameters, can have impacts on biomarkers, ${ }^{15,16}$ another experiment will be conducted in the fall (outside breeding season) in order to address the interaction between biological responses and several confounding factors.

\section{References}

1. Fleeger JW, Carman KR, Nisbet RM. Indirect effects of contaminants in aquatic ecosys- tems. Sci Total Environ 2003;317:207-33.

2. Sanchez-Dardon J, Voccia I, Hontela A, Chimonczyk S, Dunier M, Boermans H, et al. Immunomodulation by heavy metals tested individually or in mixtures in rainbow trout (Oncorhynchus mykiss) exposed in vivo. Environ Toxicol Chem 1999;18:1492-7.

3. Sanchez W, Palluel O, Meunier L, Coquery M, Porcher JM, Aït-Aïssa S. Copper induced oxidative stress in three-spined stickleback: relationship with hepatic metal levels. Environ Toxicol Pharmacol 2005;19:177-83.

4. Barillet S, Adam C, Palluel 0, Porcher JM, Devaux A. Uranium bioaccumulation and biological disorders induced in zebrafish (Danio rerio) after a depleted uranium waterborne exposure. Environ Pollut 2011;159:495-502.

5. Pottinger TG, Carrick TR, Yeomans WE. The three-spined stickleback as an environmental sentinel: effects of stressors on wholebody physiological indices. J Fish Biol 2002;61:207-29.
6. Bado-Nilles A, Jolly S, Porcher JM, Palluel 0, Geffard A, Gagnaire B, et al. Applications in environmental risk assessment of leucocyte apoptosis, necrosis and respiratory burst analysis on the European bullhead, Cottus sp. Environ Pollut 2014;184:9-17.

7. Santos R, Palos-Ladeiro M, Besnard A, Porcher JM, Bony S, Sanchez W, et al. Relationship between DNA damage in sperm after ex vivo exposure and abnormal embryo development in the progeny of the threespined stickleback. Reprod Toxicol 2013;36:611.

8. INERIS. Aluminum \& derivatives. Toxicological and environmental data sheets of chemicals; 2005. Available from: http//www.ineris.fr/substances/fr/page/21

9. INERIS. Barium. Toxicological and environmental data sheets of chemicals; 2008. Available from: http:/www.ineris.fr/substances/fr/glossaire/view/letter/B

10. GRNC, Groupe Radioécologique NordCotentin. Risques pour l'environnement. Evaluation des risques associés aux rejets chimiques des installations nucléaires du Nord-Cotentin, vol 3; December 2002, 49 and annexes.

11. Water Framework Directive - United Kingdom Technical Advisory Group (WFDUKTAG). Proposed EQS for Water Framework Directive Annex VIII substances; 2007. Available from: http//www.wfduk.org/sites/ default/files/Media/Iron\%20-\%20UKTAG.pdf

12. INERIS. Uranium. Toxicological and environmental data sheets of chemicals; 2008. Available from: http://www.ineris.fr/substances/fr/glossaire/view/letter/U

13. Rougier F, Menudier A, Troutaud D, Bosgiraud C, Ndoye A, Nicolas JA, et al. In vivo effects of zinc and copper on the development of listeriosis in zebrafish, Brachydanio rerio (Hamilton-Buchanan). J Fish Dis 1992;15:453-6.

14. Esteve C, Alcaide E, Ureña R. The effect of metals on condition and pathologies of European eel (Anguilla anguilla): in situ and laboratory experiments. Aquat Toxicol 2012;109:176-84.

15. Nikoskelainen S, Bylund G, Lilius EM. Effect of environmental temperature on rainbow trout (Oncorhynchus mykiss) innate immunity. Develop Comparat Immunol 2004;28:581-92.

16. Bowden TJ. Modulation of the immune system of fish by their environment. Fish Shellfish Immunol 2008;25:373-83. 